\title{
Persistent growth of a young andesite lava cone: Bagana volcano, Papua New Guinea
}

Article

Accepted Version

Creative Commons: Attribution-Noncommercial-No Derivative Works 4.0

Wadge, G., McCormick Kilbride, B. T., Edmonds, M. and Johnson, R. W. (2018) Persistent growth of a young andesite lava cone: Bagana volcano, Papua New Guinea. Journal of Volcanology and Geothermal Research, 356. pp. 304-315. ISSN 0377-0273 doi:

https://doi.org/10.1016/j.jvolgeores.2018.03.012 Available at https://centaur.reading.ac.uk/77215/

It is advisable to refer to the publisher's version if you intend to cite from the work. See Guidance on citing.

To link to this article DOI: http://dx.doi.org/10.1016/j.jvolgeores.2018.03.012

Publisher: Elsevier

All outputs in CentAUR are protected by Intellectual Property Rights law, including copyright law. Copyright and IPR is retained by the creators or other copyright holders. Terms and conditions for use of this material are defined in the End User Agreement. 


\section{CentAUR}

Central Archive at the University of Reading

Reading's research outputs online 


\title{
Persistent growth of a young andesite lava cone: Bagana volcano, Papua New Guinea
}

\author{
G. Wadge ${ }^{1,2}$, B.T. McCormick Kilbride ${ }^{1,3}$, M. Edmonds ${ }^{1,3}$, R.W. Johnson ${ }^{4}$
}

1. Centre for the Observation and Modelling of Earthquakes, Volcanoes, and Tectonics

\section{Department of Meteorology}

University of the Reading

Reading, UK

3. Department of Earth Sciences

Downing Street, University of Cambridge

Cambridge, UK

4. College of Asia and the Pacific

Australian National University

Canberra, Australia

\begin{abstract}
Bagana, an andesite lava cone on Bougainville Island, Papua New Guinea, is thought to be a very young central volcano. We have tested this idea by estimating the volumes of lava extruded over different time intervals (1-, 2-, 3-, 9-, 15-, 70years) using digital elevation models (DEMs), mainly created from satellite data. Our results show that the long-term extrusion rate at Bagana, measured over years to decades, has remained at about $1.0 \mathrm{~m}^{3} \mathrm{~s}^{-1}$. We present models of the total edifice volume, and show that, if our measured extrusion rates are representative, the volcano could have been built in only $\sim 300$ years. It could also possibly have been built at a slower rate during a longer, earlier period of growth. Six kilometres NNW of Bagana, an andesite-dacite volcano, Billy Mitchell, had a large, caldera-forming plinian eruption 437 years ago. We consider the possibility that, as a result of this eruption, the magma supply was diverted from Billy Mitchell to Bagana. It seems that Bagana is a rare example of a very youthful, polygenetic, andesite volcano. The characteristics of such a volcano, based on the example of Bagana, are: a preponderance of lava products over pyroclastic products, a high rate of lava extrusion maintained for decades, a very high rate of $\mathrm{SO}_{2}$ emission, evidence of magma batch fractionation and location in a trans-tensional setting at the end of an arc segment above a very steeply dipping and rapidly converging subduction zone
\end{abstract}




\section{Introduction}

Polygenetic volcanoes are characterised by a series of eruptions, typically from the same conduit and vent, building a substantial edifice up to kilometres in height, over thousands to hundreds of thousands of years. In contrast, monogenetic volcanoes never re-use the same conduit after their initial, perhaps extended, eruption. Smith and Nemeth (2017, Fig. 3) classified polygenetic and monogenetic volcanoes in terms of petrogenesis (polygenetic volcanoes being much more susceptible to variations of magma composition and storage) and volcanic architecture, responsible for vent locations. A polygenetic volcano may grow through a long history of eruptions, but be a close neighbour to an older, perhaps larger volcano, and might share the same deeper magmatic feeding system. The "birth" of new polygenetic volcanoes, particularly of andesitic composition, is much less common than those of monogenetic volcanoes. Indeed, such events are rarely observed and their significance has been little discussed.

In this paper we focus on the persistent growth of the Bagana polygenetic volcano driven by high emission rates of lava and gas. Bagana is a remote andesitic lava cone volcano on Bougainville Island, Papua New Guinea, , with no current, regular programme of instrumental ground observations and an incomplete record of historical activity (Bultitude, 1981), making it a challenging target. However, Bagana is very active and is characterised by (1) slow emplacement over months to years of crystal-rich (30-50\% phenocrysts) andesite lava flows having high levées (Wadge et al., 2012); (2) strong emission of sulphur dioxide (McCormick et al., 2012; McCormick Kilbride et al., in prep. a; Carn et al., 2017); and (3) occasional, generally short-lived, explosive eruptions (e.g. Siebert et al., 2010). It is the very slow emplacement of these thick flows that enables us to estimate lava flux at a range of intervals over several decades. In addition, we also discuss the possibility that the start of volcanism at Bagana may be linked to a large caldera-forming eruption (370 \pm 19 years BP, Rogerson et al., 1989; Siebert et al., 2010) at neighbouring Billy Mitchell volcano.

Our method is to measure the change of topography on Bagana over different intervals and from these observations to estimate the lava flux. To do this we primarily use data from satellite-borne radars (SRTM, TerraSAR-X, TanDEM-X) and from them produce differential digital elevation models (DEMs) to estimate the rate of lava extrusion. Extrapolation and topographic modelling leads to estimates of how long it has taken to build the edifice of the volcano. In section 2 we present a review of the tectonic, geological and topographical setting and eruptive history. Section 3 describes how we used the topographical datasets to estimate volumetric output and section 4 presents those results. We then discuss the volumetric flux history of Bagana, and potential links between Bagana, neighbouring volcanoes and tectonic setting. We end the paper by suggesting what future work is required to improve our understanding.

\section{Bagana Volcano}


Bagana volcano, on the island of Bougainville at $6^{\circ} 09^{\prime} \mathrm{S}, 155^{\circ} 11^{\prime} \mathrm{E}$, has a complex, regional tectonic setting dominated by the interactions of the major Pacific and IndoAustralian plates and by one of the several, intervening, minor plates. The minor Solomon Sea plate southwest of Bougainville Island is being subducted to the northeast at the New Britain Trench at a rate of about $100 \mathrm{~mm} /$ year (Chen et al., 2011) (Fig.1a). The subducted slab dips at $75^{\circ}$ beneath Bagana volcano. Furthermore, its upper surface is about $150 \mathrm{~km}$ below Bagana and about $185 \mathrm{~km}$ below the Billy Mitchell volcano further to the northeast The Solomon Islands subduction zone is the most extreme in the global compilation of Syracuse and Abers (2006), having the highest rate of plate convergence $\left(\sim 100 \mathrm{~mm} \mathrm{yr}^{-1}\right)$ and the steepest dip of the slab $\left(\sim 70^{\circ}\right)$.

A discontinuous volcanic front on Bougainville consists of a southeast-trending line of volcanoes of which Tore, Balbi, Bagana, Takuan and Taroka are the most significant (Blake, 1968). The most important event of the late-Cenozoic history of the Bougainville area was the collision of the $40 \mathrm{~km}$-thick oceanic Ontong Java Plateau, carried on the Pacific Plate, with a former northwest-facing North Solomon island arc and southwest-dipping subduction zone. The collision blocked the subduction zone, and caused reversal of arc polarity beneath the Solomon Islands, including Bougainville Island (Fig.1a). Part of the earlier southwest-dipping lithospheric slab is still evident seismically (Holm et al., 2016).

In northern Bougainville, the $137^{\circ}$-orientation of the Tore-Balbi-Bagana volcanic front (Fig. 1b) marks the line of magma rising above the subducting Solomon Sea plate which strikes about $130^{\circ}$ (Lay et al., 2017). The volcanic front in southern Bougainville is less evident, but we mapped it here by the alignment of vents at Takuan and Taroka volcanoes. The junction of the two fronts steps to the left by about 6-7 km (Fig. 1b). Chen et al. (2011) placed a boundary between the Northwest Bougainville and Southeast Bougainville arc segments (Fig.1b) about $10 \mathrm{~km}$ southeast of Bagana. Evidence for this comes from geomorphology: the whole island tilts to the northeast, with the uplift of the southwestern coast more pronounced in the Southeast Bougainville segment. Also, the aftershock areas of most large forearc earthquakes southwest of Bougainville (in 1974, 1975, 1995, 1996, 2007, 2016) terminate at the offshore extension of the segment boundary. On 22 January 2017 there was a $M_{w} 7.9$ earthquake in the subducting plate with a centroid depth of about $140 \mathrm{~km}$ below Bagana (Lay et al., 2017). The moment release rate on the Northwest Bougainville segment is about half $(\sim 50 \mathrm{~mm} / \mathrm{yr})$ the co-seismic slip rate (Chen et al., 2011). The largest volcanic edifices of both Bougainville segments have central positions: Balbi (Northwestern) and Taroka/Takuan (Southeastern) as is seen in classic volcanic fronts such as Central America (Bolge et al., 2009).

Blake and Miezitis (1967) and Rogerson et al. (1989) described the structural geology of densely vegetated Bougainville Island using air photographs and limited field observations. Rogerson et al. (1989) recognised four families of lineaments comprising: the SE $\left(137^{\circ}\right)$ direction of the volcanic front, the SSE $\left(165^{\circ}\right)$ alignment of Numa Numa, Billy Mitchell and Reini volcanoes (Fig.1b), the ESE (119 ${ }^{\circ}$ ) Atsilima Fault Zone and shorter features further north and the network of NNE-trending $\left(025^{\circ}\right)$ normal faults between the Atsilima Fault Zone and the centre of the island 
(Fig. 2). These latter two structural elements are explored later in terms of conduits for magma in the upper crust of Bougainville.
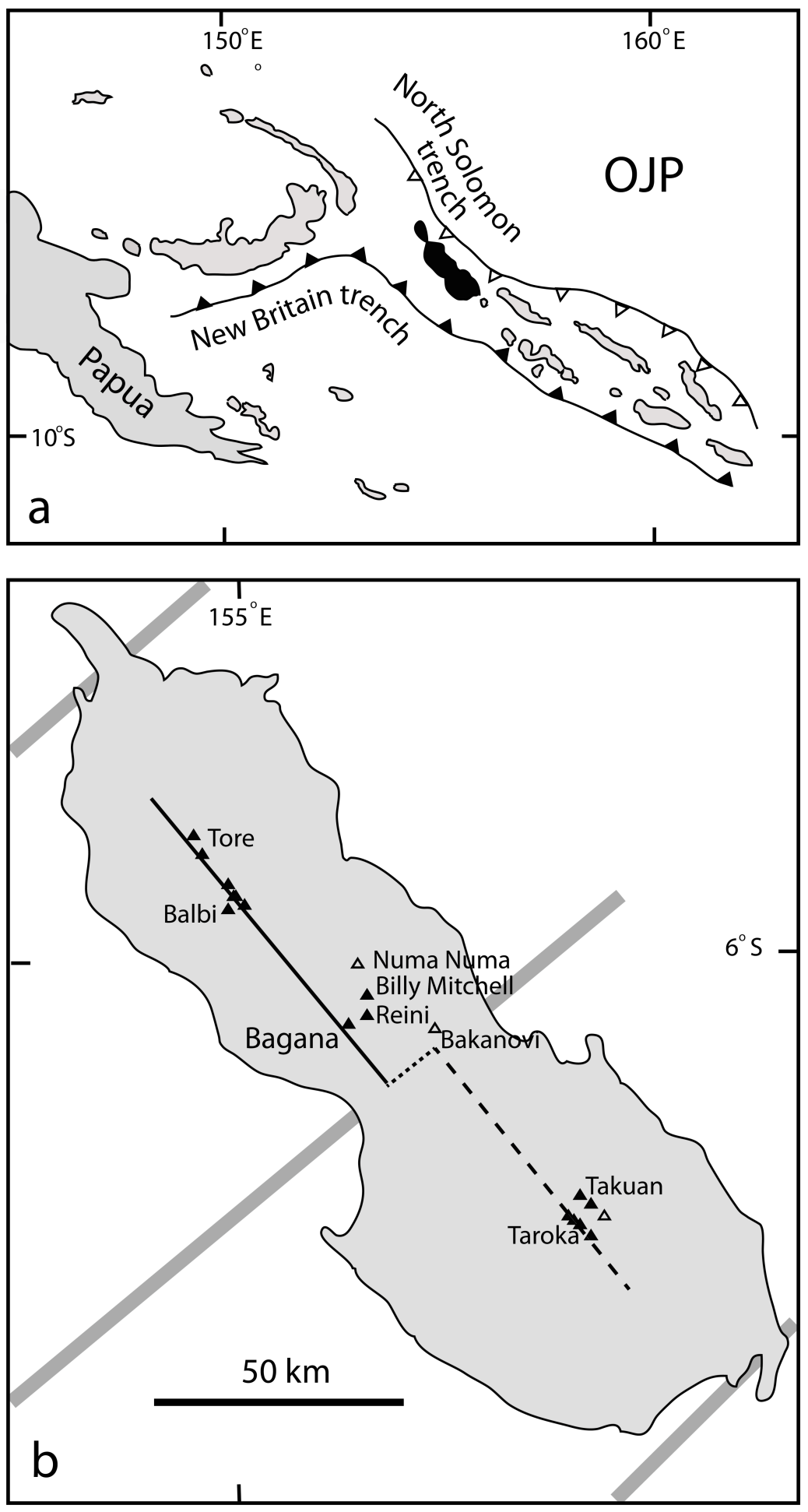

Fig. 1 Sketch maps of the tectonic setting of Bougainville. (a) The island of Bougainville (black) is sandwiched between the inactive subduction zone involving the Ontong Java Plateau (OJP) at the North Solomon Trench (white triangulated line) and the active subduction zone of the Solomon Sea Plate at the North Britain Trench (black triangulated line). (b) Location of volcanoes on Bougainville (black triangles = active, white triangles = extinct) after Bultitude (1981). The continuous black line in northern Bougainville is the volcanic front and the dashed black line in southern Bougainville is the presumed trace of 
the front. The three grey lines are the arc segment boundaries on Bougainville after Chen et al. (2011).

\section{Geological Setting}

Bagana is the only one of the Bougainville volcanoes with confirmed eruptive activity in the last two hundred years. It has a basement of volcanic rocks, comprising the Keita Volcanics to the southeast and unnamed, presumed to be of Neogene age, volcanic rocks to the northwest (Blake and Miezitis, 1967). On the northwest margin of Bagana, about $2.5 \mathrm{~km}$ from the vent, is a $200 \mathrm{~m}$ high volcanic dome of unknown age. East of Bagana is a little studied eroded lava cone volcano, Reini (Blake and Meizitis, 1967) (Fig. 2). It is slightly smaller than Bagana and has a ridge-like morphology oriented SSE that is not present at Bagana (Fig. 2). Reini is considered to pre-date the BM2 eruption of Billy Mitchell Volcano (Rogerson et al., 1989) and the whole-rock geochemistry compositions of the Reini lavas are similar to those of Bagana lavas (Rogerson et al., 1989). This leads to the notion that Reini could be the predecessor of Bagana. We return to this idea later.

Six kilometres to the NNE of Bagana is the Billy Mitchell volcano, which has a lakefilled caldera that last erupted in $370 \pm 19 \mathrm{yr}$ BP (Rogerson et al., 1989) producing a plinian explosion and widely distributed dacitic, pumiceous and phreatomagmatic tephra fall deposit and a large ignimbrite (Fig. 3). These comprise the BM2 event, with a total volume of about $13.5 \mathrm{~km}^{3}$. This eruption was ranked the $17^{\text {th }}$ most effective in reducing tree ring density in the northern hemisphere in the last 600 years (Briffa et al., 1998). Prior to that, another large plinian pumice and phreatomagmatic tephra (but no ignimbrite) eruption in $937 \pm 19 \mathrm{yr}$ BP occurred, with a total volume of about $7 \mathrm{~km}^{3}$. Wherever found, deposits from Bagana overlie the BM2 deposit. The BM2 airfall deposit is not seen overlying the current lava surface of Bagana (it should be about $0.4 \mathrm{~m}$ thick). To the north-northwest of Billy Mitchell is the extinct Numa Numa volcano (Figs.1, 2).

The southwest flanks of Bagana are drained by the Torokina and Saua Rivers. The headwaters of both rivers are sometimes reported as being hot, presumably via interaction with recent, still-hot lava flows or because of deeper groundwater convection. To the north-northeast of the summit is an embayed lake about $1 \mathrm{~km}$ across (Fig. 2). This apparently sits on an old (pre-Bagana) drainage pathway to the south following the western flank of Reini volcano.

The basaltic andesite/andesite (53-59 weight $\% \mathrm{SiO}_{2}$, Bultitude et al., 1978) magma of Bagana is rheologically disposed to form thick (>> $20 \mathrm{~m}$ ) lava flows (e.g. Arenal Volcano, Costa Rica) but not Peléan domes (e.g. Soufrière Hills, Montserrat). Also Bagana is capable of sustaining a high emission rate of volcanic gas during both eruptions and inter-eruptive pauses (McCormick Kilbride et al., in prep.), but relatively little explosive ash generation. This combination is highly characteristic of this volcano.

The morphology of Bagana is that of a lava cone with a summit crater about $200 \mathrm{~m}$ across from which lava is emitted to form long-lived (months to years), channelized, flows. A low dome sometimes fills the crater to a height of up to $40 \mathrm{~m}$ above the rim, and this can be destroyed by explosions. The lava flows are of calcalkaline, andesite 
composition, with $30-50 \%$ phenocrysts of plagioclase, subordinate clinopyroxene, Fe-Ti oxides and sparse, large phenocrysts of hornblende, particularly in the more silica-rich, pre-1943 rocks. There are rare, coarse-grained, silicic inclusions and one analysed mafic inclusion (Bultitude et al., 1978; Rogerson et al., 1989). Future new petrological analysis may reveal the nature of any magma mixing involved in andesite magma formation.

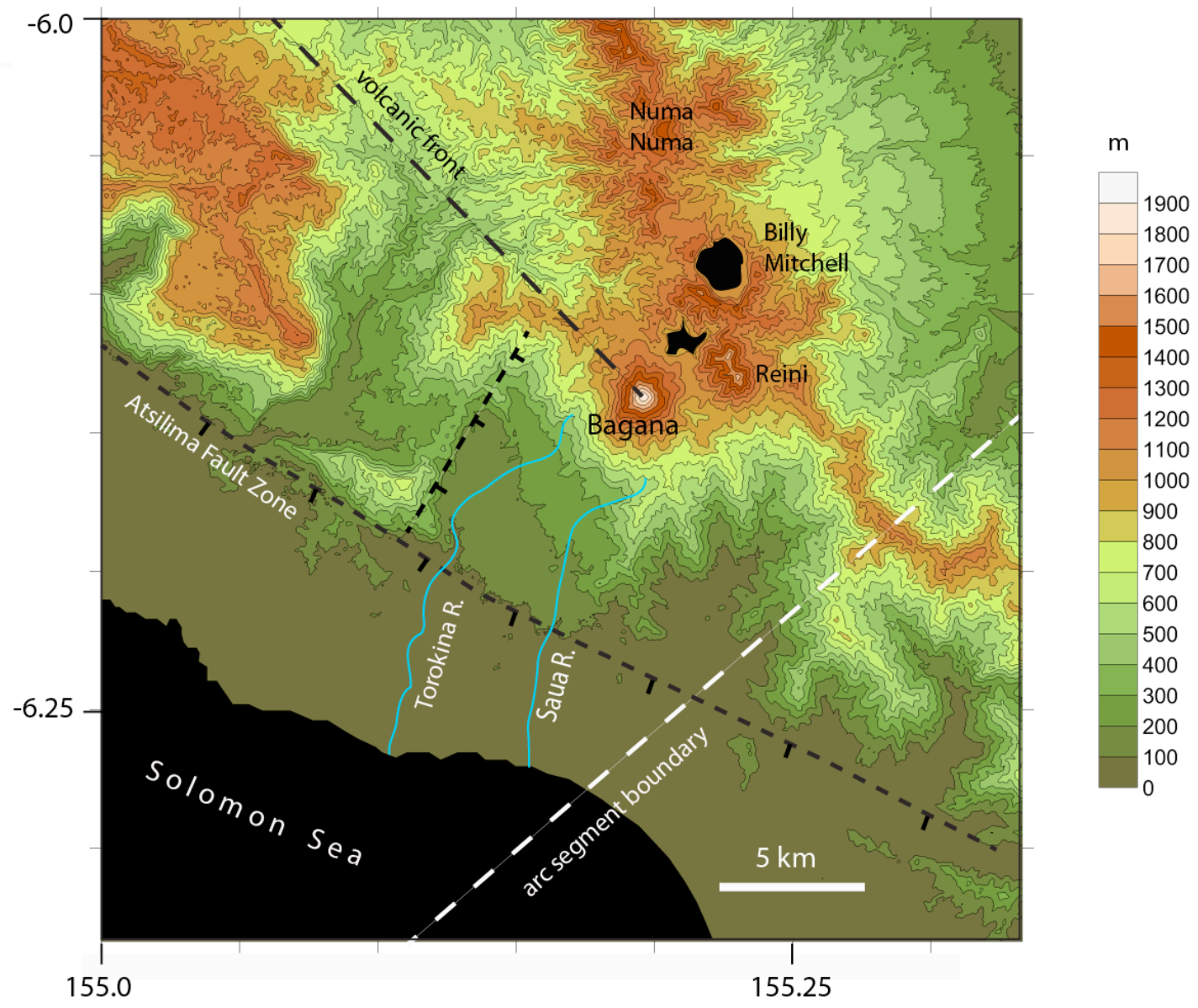

Fig. 2 Map of the area around Bagana volcano, Bougainville. Topography is taken from the SRTMGL1 product; contours are every $100 \mathrm{~m}$ above sea level. The Torokina and Saua Rivers are shown in blue. The active volcanic front in northern Bougainville is shown by the long-dashed black line. The subducting plate beneath Bougainville is segmented and one of the boundaries is shown by a white dashed line (Chen et al., 2011), the middle one of three such boundaries shown in Fig.1b. The short-dashed black line is the Atsilima Fault Zone (ticks on the downthrown side), described by Rogerson et al. (1989), which is at the back of the coastal strip of central Bougainville. Note the SSE $\left(165^{\circ}\right)$ alignment of volcanoes (Numa Numa, Billy Mitchell and Reini) that sit behind the volcanic front of northern Bougainville.

The lava flows increase in width (up to $500 \mathrm{~m}$ ) and thickness (up to $180 \mathrm{~m}$ ) downslope, sometimes branching to form compound units, with a maximum length of about $4 \mathrm{~km}$, to the south. Levéed channels with near vertical inner walls are common in the medial parts of the flow and these can be repeatedly filled and drained (Wadge et al., 2012). Between flows, the talus from levées accumulates along with minor pyroclastic ejecta. 
White, water vapour-rich plumes commonly emanate from the summit crater and the margins of active lava flows. Often the summit plumes contain ash, sometimes of secondary origin, that can reach altitudes of 3-4 km above sea level. The Bagana plume is also notably $\mathrm{SO}_{2}$-rich (McCormick et al., 2012; McCormick Kilbride et al., in prep. a; McGonigle et al., 2004) and has, on average, the third highest $\mathrm{SO}_{2}$ flux among persistently active volcanoes worldwide (measured by satellite between

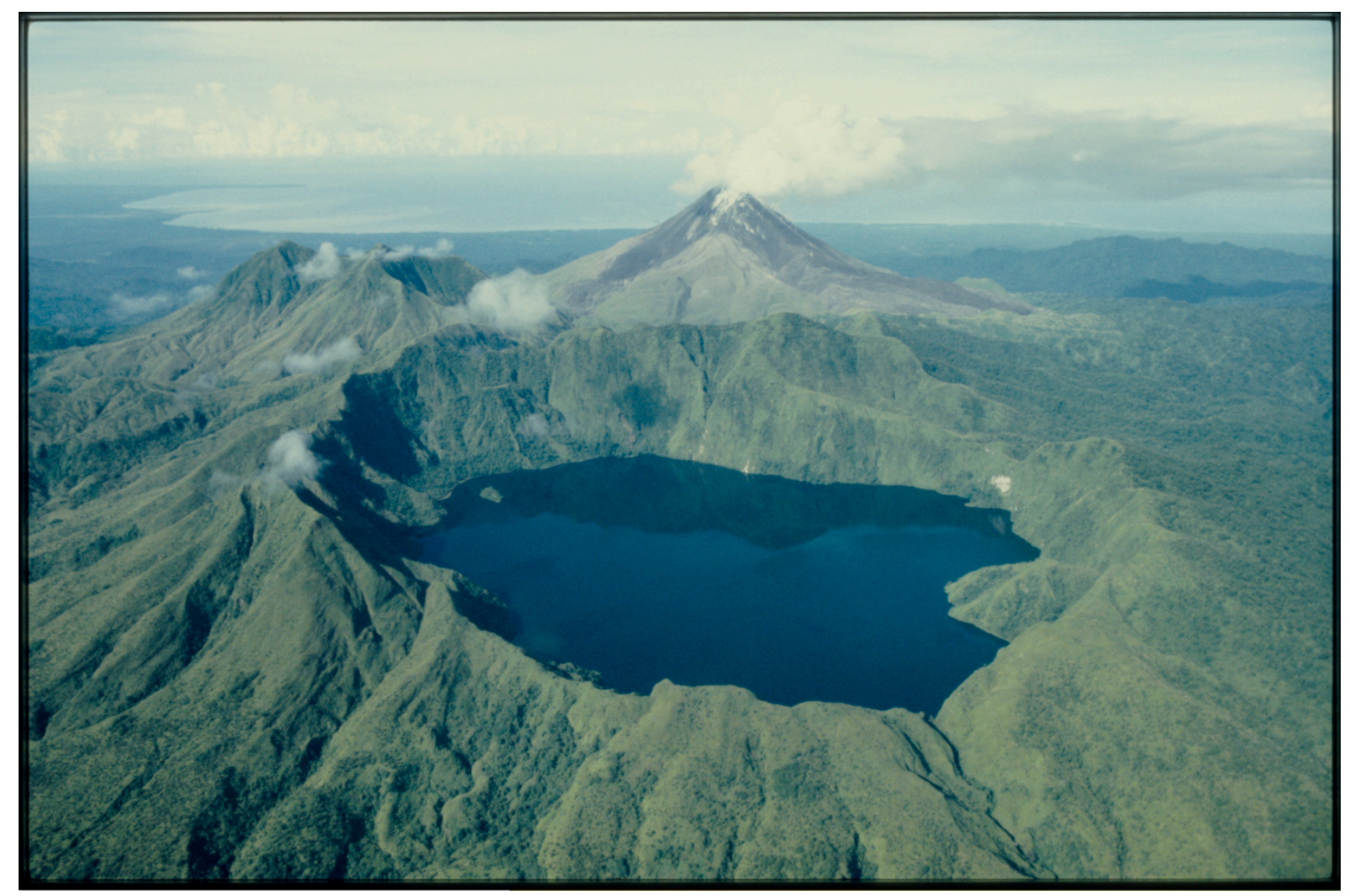

Fig. 3 Aerial photograph of Billy Mitchell caldera lake from the northeast in 1987. Bagana and Reini volcanoes are in the distance on the right and left respectively. The lake has a maximum diameter of $2.26 \mathrm{~km}$

2005-2015; Carn et al., 2017). There are occasional pyroclastic density currents (PDCs) and debris avalanches and lahars, though these have been little studied. The deposits from these mainly accumulate adjacent to the southwest sector of the volcano where a fan of re-worked volcaniclastic material extends to the Solomon Sea over a plain about $20 \mathrm{~km}$ long, bounded by the Torokina and Saua Rivers (Fig. 2). New PDC deposits are known to extend up to 5-6 km over the plain (e.g. 30 May 1966, Bultitude (1976)).

\section{Eruptive History}

The first reports of Bagana as a volcano were based on observations from ships in the 1800s (Bultitude, 1981, Johnson, 2013). The distinctive channelised surface of the volcano was first reported as "numerous furrows and channels" by J.P. Wilson of the ship Gypsy in 1842. The presence of "vapours", presumably from the summit plume or an active lava flow, is also noted in early accounts. In 1884 Guppy (1887) tells of locals reporting a "great explosion" in that year that "killed a number of natives". He states that Bagana had been "in continual eruption for 15-20 years." A 
field visit by K. Sapper, the German volcanologist, in July 1908 occurred a few days after volcanic activity. From these, albeit limited, observations, the activity of Bagana during the century between 1842 and 1943 seems to have been similar to that of the behaviour recorded later (Bultitude, 1981, Johnson, 2013): slow-moving lava flows lasting years, near-continuous plumes of volcanic gas and occasional tephra with much more infrequent large explosions and PDCs.

Beginning in 1943 a variety of aerial photographs of Bagana were taken. By 1967 Blake and Mietzitis (1967, Fig. 10b) sketched the first map of the location and date of lava flows emplaced between 1943 and 1965, largely based on these photographs. The thickness and slow-moving nature of the flows means that some flows can be tracked and mapped quite well. However, infrequent observations mean that there are some inaccuracies about the locations of flows, their longevity and whether they represent newly sourced flows or branched channels from the same compound lava flow. Bultitude (1976, Fig.4) was able to draw a much more detailed map using photographs from 1943, 1947, 1962, 1963 and 1976. This was updated by Bultitude at al. (1978, Fig. 5), by Bultitude and Cooke (1980) and by Rogerson et al. (1989, Fig. 2.31). Other relevant reports of field observations are found in Fisher (1956, 1957), Branch (1967) and Taylor (1956).

With the advent of satellite imagery in the 1970s, the resulting synoptic views of the volcano have enabled the locations of the more recent lava flows to be captured with improved fidelity. We have extended the earlier lava flow mapping from 1988 to 2017 using images from satellites, mainly TerraSAR-X radar data (Wadge et al., 2012) and Aster infrared and Landsat optical data, though cloud cover is a common problem in the latter. The online archive (2000-present, hosted at https://ava.jpl.nasa.gov) of thermal infrared Aster images is particularly valuable in giving rare, but sometimes clear evidence of the direction of radiating linear features (active channelized lava flows) extending down-slope from the circular summit crater.

Figure 4 shows a map of lava flows, as of 2017, derived from a combination of past mapping (e.g. Bultitude, 1976) and satellite images (since 1970). Figure 5 shows a time-line of eruptive activity: lava flows, explosions and PDCs from 1943 to 2017. Explosions are rare and of moderate size (mainly $<4$ on the Volcano Explosivity Index). It is probable that debris avalanches occur more frequently and are underrepresented in Fig.5.

The dominance of lava flows is evident from Figure 4 with flows active about $70 \%$ of the time between 1943 and 2017. There are now only two main areas of lava flows dating from pre-1943, to the east-southeast and west-northwest of the summit (labelled pre-1943 in Fig. 3). Lava flows since 1943 have covered about $85 \%$ of the surface area of the volcano. This shows that the flows in this most recent period are just as long, if not longer, than those in the earlier history of the volcano.

The last recorded lava flow was to the northwest in 2014 and there was no obvious change in lava flow activity at Bagana reported by Rabaul Volcano Observatory in response to the $M_{w} 7.9$ subduction slab earthquake of 22 January 2017, $\sim 140 \mathrm{~km}$ beneath the volcano. 


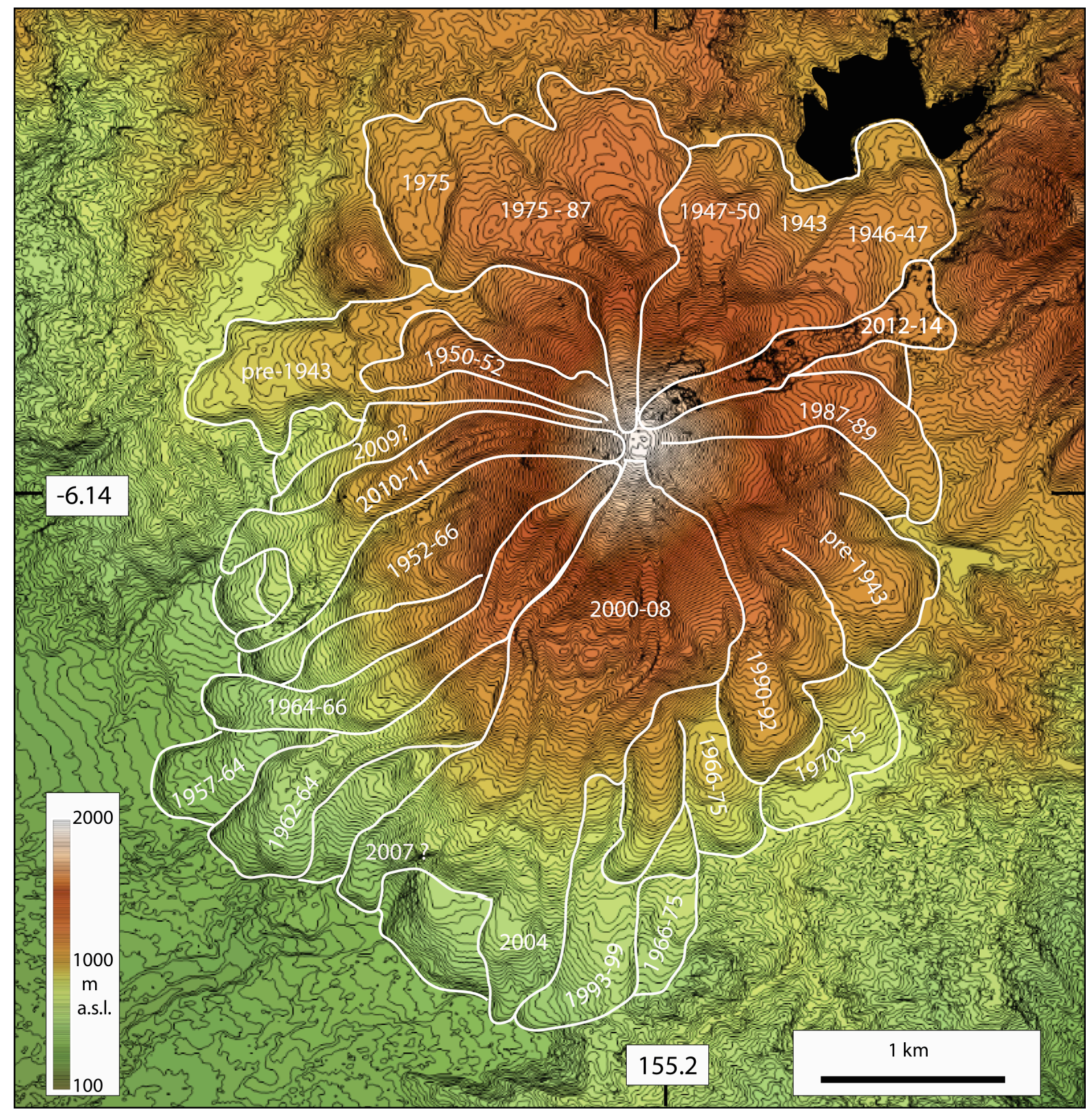

Fig.4 Map of the outlines of lava flows at Bagana Volcano from 1943 to 2017. The topography is derived from TanDEM-X global data with $10 \mathrm{~m}$ contour intervals. Tick-marks of latitude and longitude (degrees) are shown. For earlier maps based on aerial photography see Bultitude (1976), Bultitude et al. (1978), Bultitude and Cooke (1981) and Rogerson et al. (1978). 

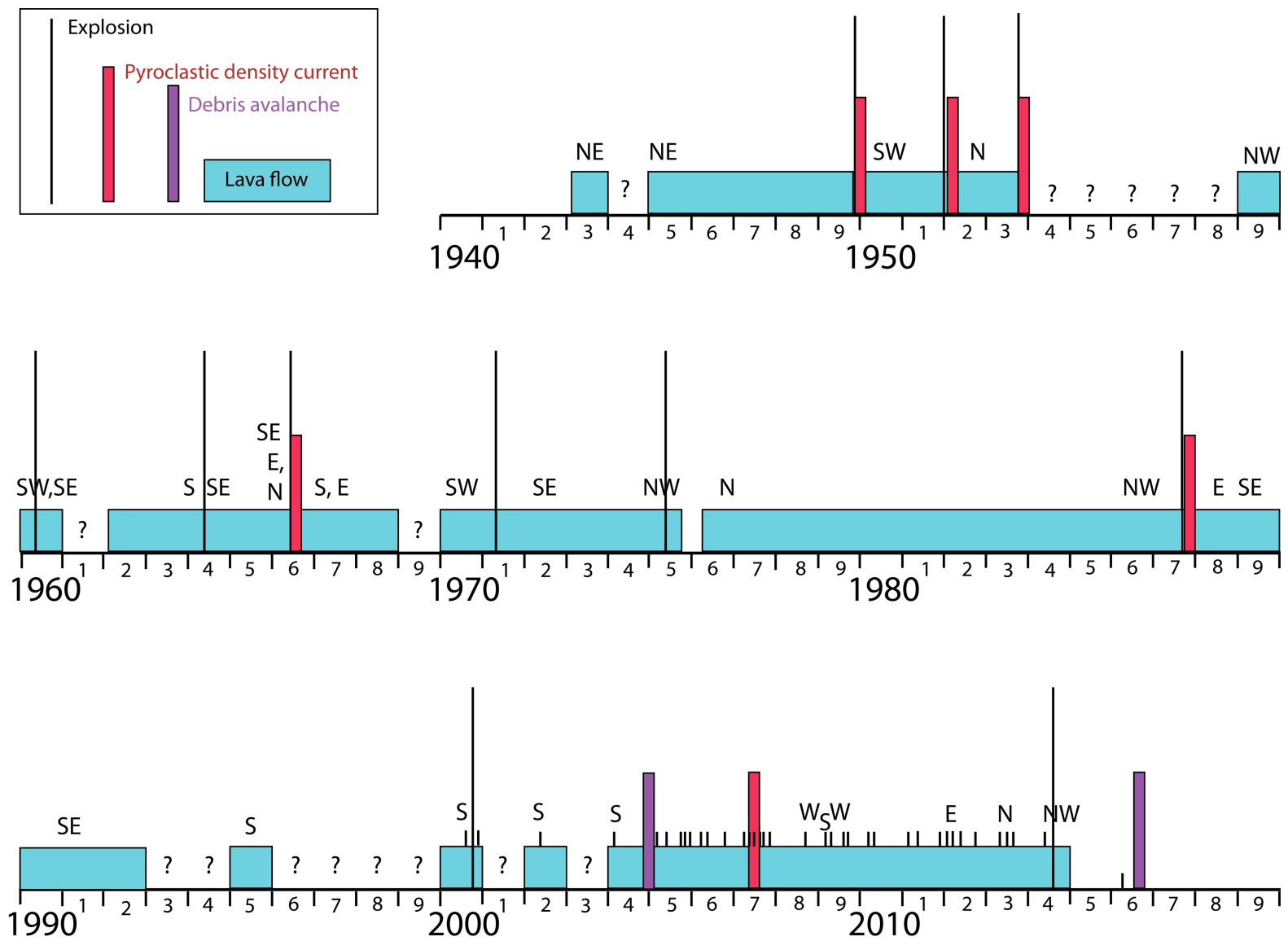

Fig.5 Time-line showing four main types of volcanic activity at Bagana Volcano from 1943 to 2017 (legend top left). The directions of lava flow, particularly at times of change, are shown by cardinal and ordinal letters. From 2000 to 2014 the evidence for lava flow direction from Aster thermal images is indicated; each black tick mark represents a separate image. Question marks denote periods of no reports of active lava flows for that year (note the period from 1988 - 1998 was marked by civil war on Bougainville Island).

The temporal and spatial patterns of lava flow emplacement (Figure 4,5) show decadal scale episodes of common behaviour separated by periods of no lava flows and/or explosive behaviour and distinct switches from one sector of emplacement to another. Table 1 lists these decadal-scale episodes.

Table 1 Decadal-scale episodes of lava flow emplacement and compositional range

\begin{tabular}{|c|c|c|c|}
\hline Episodes & $\begin{array}{l}\text { Duration } \\
\text { (years) }\end{array}$ & Magma batch: 1-3 (reference) & $\begin{array}{l}\mathrm{SiO}_{2} \text { content range } \\
\text { wt \% (number of samples) }\end{array}$ \\
\hline pre - 1943 & - & 1 (Bultitude et al., 1978) & $56.0-57.6 \quad(10)$ \\
\hline $1943-1953$ & 11 & 2 (Bultitude et al., 1978) & $52.9-53.8$ (8) \\
\hline $1957-1967$ & 10 & 3 (Bultitude et al., 1978) & $54.9-55.5(6)^{1}$ \\
\hline $1970-1975$ & 6 & 3 (Bultitude et al., 1978) & $54.9-55.5$ \\
\hline $1975-1987$ & 13 & & \\
\hline $1987-1999$ & 13 & 3 (Rogerson et al., 1989) & $55.2-55.8 \quad(3)$ \\
\hline $2000-2008$ & 9 & & \\
\hline $2009-2014$ & 6 & $\begin{array}{l}3 \text { (McCormick Kilbride et al., in } \\
\text { prep. b) }\end{array}$ & $55-56$ \\
\hline
\end{tabular}

1. combined 1957-1975 
Bultitude et al. (1978) found that the geochemistry of the 1943-1953 lavas had a more mafic character than that of the 1957-1975 period (Table 1). Also, lava flows older than 1943 that were sampled had the most silicic whole rock compositions. Rogerson et al. (1989) reported that samples from 1987-88 also fit the range shown by the 1959-75 lavas. Bultitude et al. (1978) argued for three geochemically distinct batches of magma (1-3, Table 1 ) being delivered at decadal scales.

\section{Method}

We measure the volume of magma erupted from Bagana volcano over different periods using variants of the principle of the subtraction of DEMs. We apply this to four main intervals: 2010-2011, 2000-2014, 1945-2014 and Pre-Bagana-2014. The volumes estimated are those generated from "topographic" surfaces. We do not have measurements of bulk densities of the volcanic deposits that would enable us to calculate dense rock equivalent (DRE) values. In the Discussion we do use some speculative DRE estimates.

The uncertainties associated with the different DEM epochs are discussed below. The uncertainties for the 2010-11 study are calculated using measurements of very high resolution images of area and shadow and a model flow budget (Wadge et al., 2012). In general for the TanDEM-X and SRTM derived data we have calculated uncertainties using surface difference measurements from regions away from the parts of the volcano that should have had changes in surface height in that interval. These uncertainties are measured as standard deviations and are plotted in Fig.9.

\section{$2010-2011$}

Wadge et al. (2012) measured the emplacement of a compound lava flow on the west flank between October 2010 and December 2011 (Fig. 4). They used amplitude change difference images derived from TerraSAR-X high-resolution images to map channel and breakout flow. Using radar shadowing on these images, they estimated the volumetric flow at intervals of 11 days (and longer) and we use those volumes here to calculate the mean extrusion rate over 14 months.

2000-2014

We calculate the difference between the topography of Bagana measured in 2000 and 2014 from two DEMs acquired by spaceborne radars. In February 2000 the Shuttle Radar Topography Mission (SRTM) employed a C-band synthetic aperture radar in single-pass, bistatic, interferometry mode to acquire a global DEM (Farr et al., 2008). 3-arc second (90 m horizontal posting) and 1-arc second (30 m posting) DEMs of Bagana were acquired from the SRTMGL3 and SRTMGL1 products respectively. In contrast, the global DEM created by TanDEM-X involved two X-band radars on separate satellites that imaged the Earth repeatedly. In Bagana's case this area was sampled mainly in 2011 , but also in 2012-14. The TanDEM-X global DEM has a horizontal resolution of $12 \mathrm{~m}$ ( 0.4 arc-seconds). The difference between the 
SRTM and the TanDEM-X DEMs gives a measure of the volume of lava added to the volcano in the 15 years between the two missions.

Both the SRTM and the TanDEM-X DEMs of Bagana require careful modification to extract the optimal volumetric differences (Nuth and Kaab, 2011; Jaber et al., 2013). Both sets of products are issued in tiles of one by one degrees of latitude and longitude. The different cell sizes, 3 arc-seconds and 1 arc-seconds for SRTM and 0.4 arc-seconds for TanDEM-X necessitate some resampling. We have chosen to oversample the SRTM DEMs to the 0.4 arc-second posting of the TanDEM-X product. The SRTM elevation data are referenced to the WGS84/EGM96 geoid whilst the TanDEM-X elevations are referenced to the WGS84 ellipsoid in the WGS84-G1150 datum. At the location of Bagana, the ellipsoid is about $72 \mathrm{~m}$ above the geoid (mean sea level) and the TanDEM-X data were converted accordingly.

The local quality of the elevation data depends on several factors, including the terrain slope relative to the radar lines-of-sight and the nature of the surface (e.g. variable cover of vegetation). Generally the quality of both the SRTM and TanDEM-X DEMs is good over the volcano, largely because of the dominance of rocky surfaces. This is reflected in the metadata available. For the TanDEM-X DEM between 5 and 8 images were acquired to cover the volcano and the resultant standard deviation height error map for each pixel is lower than for much of vegetation-covered part of Bougainville (DLR, 2016).

\section{$1945-2014$}

A series of one-inch-to-one-mile topographic maps of Bougainville was created in 1945 by the Australian Army Survey Corps using aerial photogrammetry (Bougainville Island, 1945). The sheet that covers Bagana has contours at intervals of 50 feet that are quite generalised, particularly in vegetated terrain off the volcano, with an absolute error of many tens of metres. The contours were digitised and interpolated using kriging to a latitude-longitude DEM grid at TanDEM-X precision (0.4 arc-seconds). This, together with the TanDEM-X 2014 DEM, was used to estimate the volume of lava that accumulated between 1945 and 2014.

Pre-Bagana - 2014

To estimate the total volume of the Bagana edifice we need to know the shape of the pre-volcano surface. Bagana sits on a regional slope to the Solomon Sea about 20 $\mathrm{km}$ to the southwest (Fig. 2). This can be seen by the greater distance from the vent to the southwest edge of the volcano ( 3-4 km distance), than from the northeast edge $(\sim 2 \mathrm{~km})$. In Figure 6 three representative, but arbitrary, models (1-3) of the surface that forms the base of the Bagana edifice, are shown in profile, oriented NNE through the summit crater. In three dimensions these model surfaces extend to the edges of the current edifice footprint. Model 1 is slightly convex upward with the surface at about $1000 \mathrm{~m}$ a.s.l. (above sea level) below the vent, Model 2 is planar and intersects the vent conduit about $800 \mathrm{~m}$ a.s.I and Model 3 is concave upwards with a pronounced break of slope at about $500 \mathrm{~m}$ a.s.l., a shape like that of a collapse amphitheatre. We have modelled these surfaces in 3D and calculated the volumes of the edifice above them as measured in 2014 . We note that there is no morphological evidence of an edifice collapse event at Bagana. 


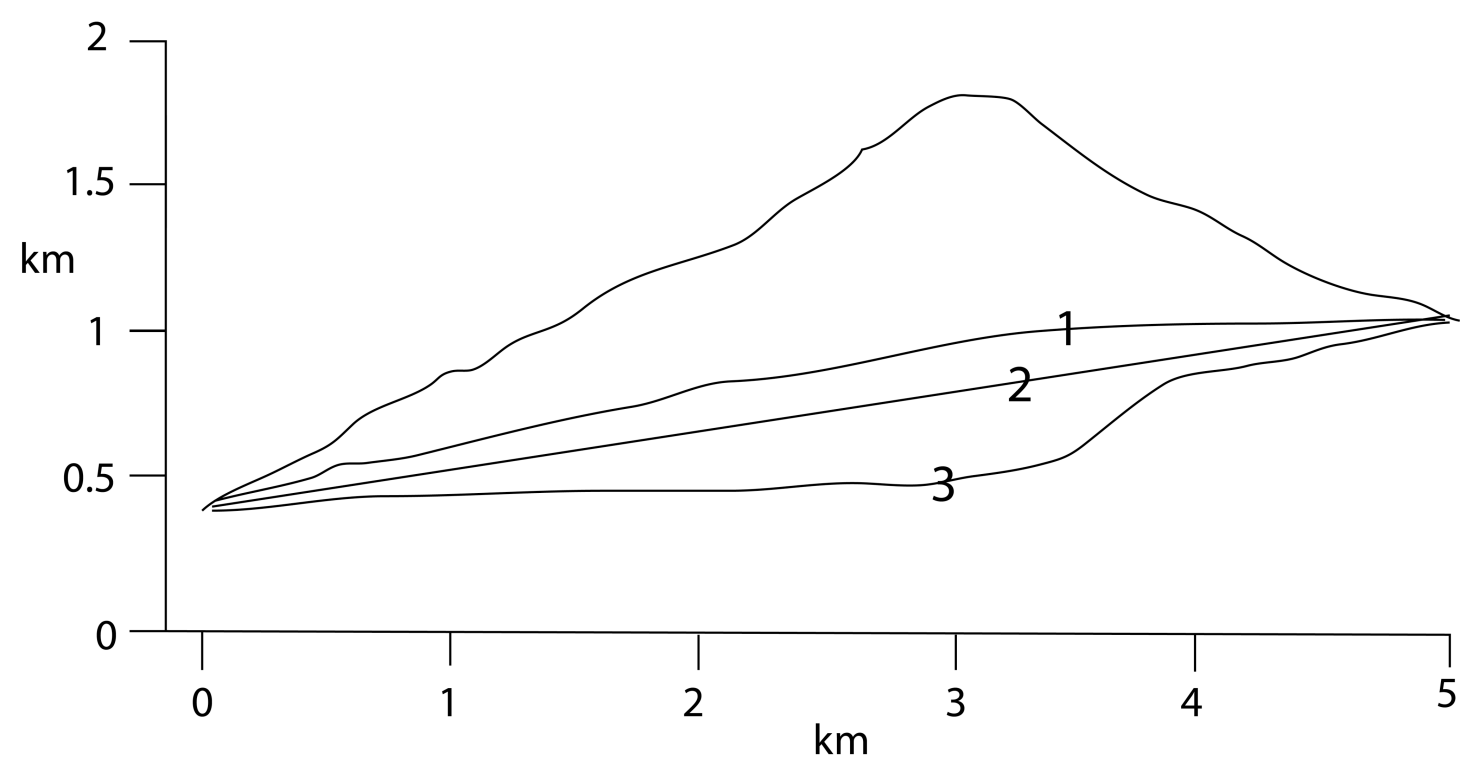

Fig. 6 Cross section profiles (SSW (left) to NNE (right)) across Bagana showing the 2014 surface of the volcano and three models $(1,2,3)$ of the basement topography on which the volcano was built (see text).

\section{Results}

\section{$2010-2011$}

The cumulative total volume (not dense rock equivalent) of erupted lava measured over 20 intervals between October 2010 and December 2011 is $32.6 \pm 12 \times 10^{6} \mathrm{~m}^{3}$ (Wadge et al., 2012). The average extrusion rate is $0.92 \pm 0.35 \mathrm{~m}^{3} \mathrm{~s}^{-1}$ delivered in three discrete pulses with a range of rates from 0.3 to $1.8 \mathrm{~m}^{3} \mathrm{~s}^{-1}$, though we only use the 14-month average values here. Over this period of high frequency/high resolution observations by TerraSAR-X the lava flow channel was repeatedly filled, overflowed, drained and branched; typical of many earlier periods of active lava flow at Bagana (e.g. Bultitude and Cooke, 1981). The dynamic bulk viscosity of the lava flow in mid2011 was estimated by Wadge et al. (2012) as $3 \times 10^{10} \mathrm{~Pa} \mathrm{~s}$, using the Jeffery equation.

$2000-2014$

During this 15-year period lava flowed in three main directions: $S$ (2000-2008), W (2009-2011) and E (2012) (Figure 7). There was some flowage to the north but this is poorly represented in the DEMs and is not shown. The 2000-2008 flows were a continuation of those southerly flows begun in 1993, with distal emplacement of lava from 2004 to 2008 occurring to the west of those of 2000-2003. The southern flow field produced during this 9-year period accumulated up to $180 \mathrm{~m}$ of lava at a break of slope between elevations of 1300 and $800 \mathrm{~m}$ a.s.l. (Figure 2, 5). This is similar to the pattern shown for the 2008 to 2011 western flows (Wadge et al., 2012, Figs. 2, 5). The 2012 east flow is shorter, narrower and thinner. The TanDEM-X DEM is 
largely derived from data acquired in 2011 and is of good quality. However, the 2014 data that captures the 2012-14 lava flows is of poorer quality and this is evident in the disconnected representation of parts of the 2012 flow (Fig. 7) (perhaps due to unwrapping errors on steep slopes) and the true volume of these later flows may be underestimated.

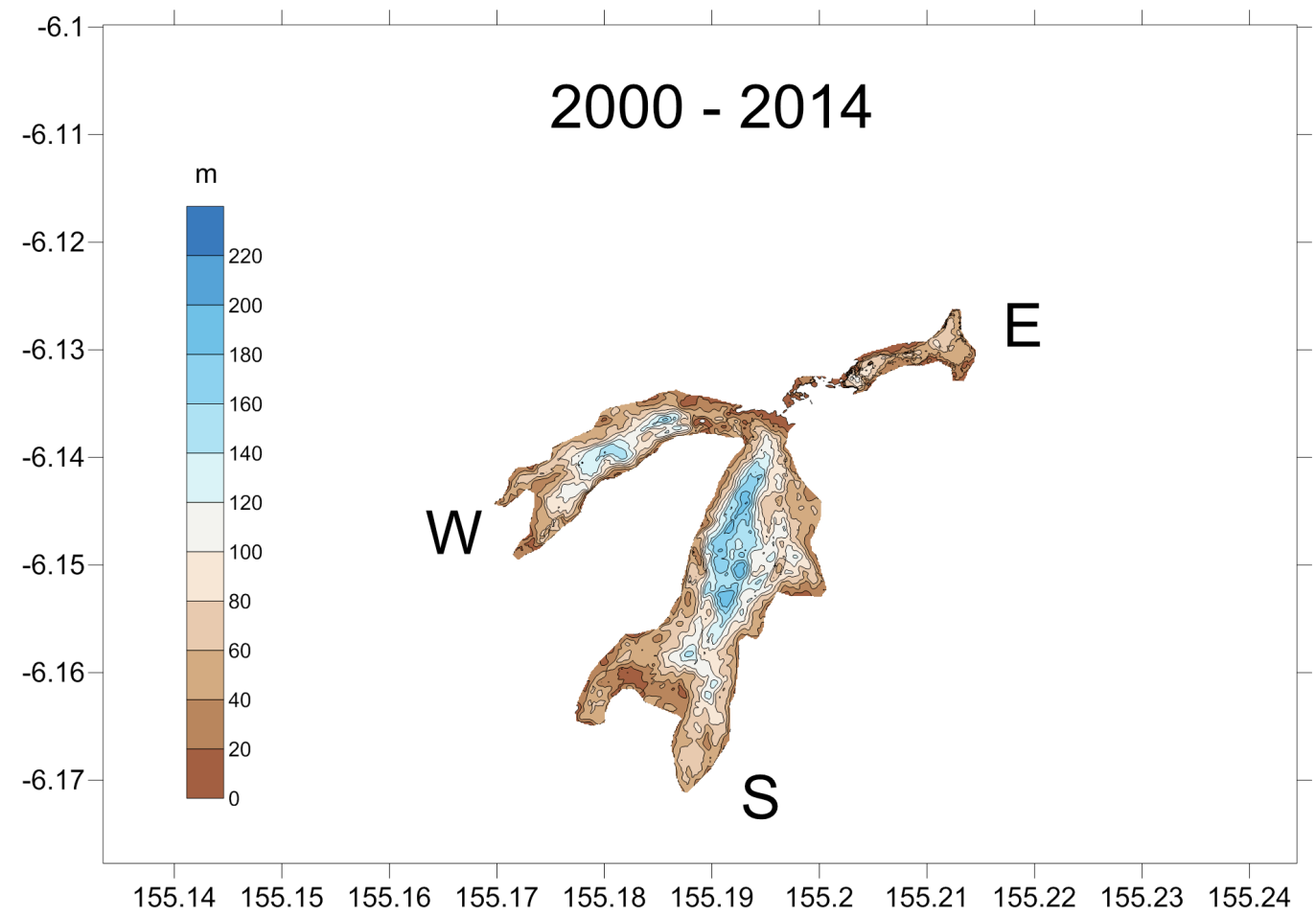

Fig.7 Lava thickness change (contours every 20 m) measured over 15-years (2000-2014) from the difference between SRTMSG1 and TanDEM-X DEMs. Three distinct flow fields are used: $S, W$, and $E$.

In total $419 \pm 79 \times 10^{6} \mathrm{~m}^{3}$ of lava were erupted in the 15 years at an average rate of $0.89 \pm 0.17 \mathrm{~m}^{3} \mathrm{~s}^{-1}$. The volumes and extrusion rates from the three spatially distinct components of the flows are given in Table 2 together with the rates of the Wadge et al. (2012) study. The 2000-2008 and the 2009-2011 extrusion rates are very similar $\left(1.06 \pm 0.24\right.$ and $\left.0.95 \pm 0.25 \mathrm{~m}^{3} \mathrm{~s}^{-1}\right)$, but the 2012-2014 extrusion rate is about half $\left(0.43 \pm 0.18 \mathrm{~m}^{3} \mathrm{~s}^{-1}\right)$ the earlier rate. This may be partly due to the poorer representation of these lavas in the DEM as mentioned earlier.

Table 2 Periods over which lava volumes and extrusion rates have been calculated

\begin{tabular}{|l|l|lc|ll|}
\hline & \multicolumn{2}{|l|}{ Period } & \multicolumn{2}{|l|}{ Volume extruded } & \multicolumn{2}{|l|}{ Extrusion rate } \\
& $(\mathrm{yr})$ & $\left(10^{6} \mathrm{~m}^{3}\right)$ & {$[\mathrm{s.d}]$.} & $\left(\mathrm{m}^{3} \mathrm{~s}^{-1}\right)$ & {$[\mathrm{s.d}]$} \\
\hline $1945-2014$ & 70 & 2209 & {$[1163]$} & 1.00 & {$[0.53]$} \\
\hline $2000-2014$ & 15 & 419 & {$[102]$} & 0.89 & {$[0.22]$} \\
\hline $2000-2008$ & 9 & 302 & {$[67]$} & 1.06 & {$[0.24]$} \\
\hline $2009-2011$ & 3 & 90 & {$[24]$} & 0.95 & {$[0.25]$} \\
\hline
\end{tabular}




\begin{tabular}{|l|l|ll|ll|}
\hline $2012-2014$ & $2^{1}$ & 27 & {$[11]$} & 0.43 & {$[0.18]$} \\
\hline $2010-2011^{2}$ & 1.2 & 32.6 & {$[12]$} & 0.92 & {$[0.35]$} \\
\hline
\end{tabular}

1. Assumed only 2 years of extrusion

2. Values from Wadge et al. (2012)

\section{$1945-2014$}

The increase in volume of lava in 70 years is $2.2 \pm 0.9 \mathrm{~km}^{3}$ (Fig. 8), giving an extrusion rate of $1.0 \pm 0.5 \mathrm{~m}^{3} \mathrm{~s}^{-1}$ (Table 2). The differential DEM (Fig. 8) shows that most of the footprint of the volcano had a positive increase in height between 1945 and 2014. The standard deviation of elevation in the difference map is about $50 \%$ (Table 2). There are several possible contributors to this. There could be a long wavelength projection error. Photogrammetry is least accurate over dense forest where there are no good correlation points. The areas of densest vegetation on Bagana are likely to be over the oldest lava flow surfaces (pre-1943), and most susceptible to elevation error. Areas to the WNW and, particularly to the ESE of the summit are pre-1943 and correspond to areas of negative elevation change (Fig. 8). Such signals could conceivably be due to mass wasting events with either a shallow or deep basement (the latter exemplified by Model 3 of Fig. 5) failure surface. However, there is no obvious downslope area of deposition from such events particularly to the southeast (Fig. 4).

Pre-Bagana-2014

The volume of the edifice above the convex basement (Fig. 6, Model 1) is $5.1 \mathrm{~km}^{3}$, $6.4 \mathrm{~km}^{3}$ for the planar surface Model 2 and $9.6 \mathrm{~km}^{3}$ for the concave slope Model 3 . These three models of the Bagana basement surface give the likely range of the volume of the volcano's edifice.

Height

There is evidence from ground survey and space-borne geodesy of the upward growth of the crater rim/dome (Table 3). The summit of Bagana has risen by about $150 \mathrm{~m}$ in 70 years.

Table 3. The maximum heights of Bagana volcano

\begin{tabular}{|c|c|c|}
\hline Date & Height (m asl) & Source \\
\hline 1945 & 1742 & Bougainville Island (1945) \\
\hline 1967 & 1746 & Blake and Miezitis (1967) \\
\hline$?$ & 1855 & $\begin{array}{l}\text { Smithsonian Institution, Global Volcano } \\
\text { Program }\end{array}$ \\
\hline 2000 & 1867 (1864) & SRTM(GL1) (GL3) \\
\hline 2011(14) & 1897 & TanDEM-X \\
\hline
\end{tabular}




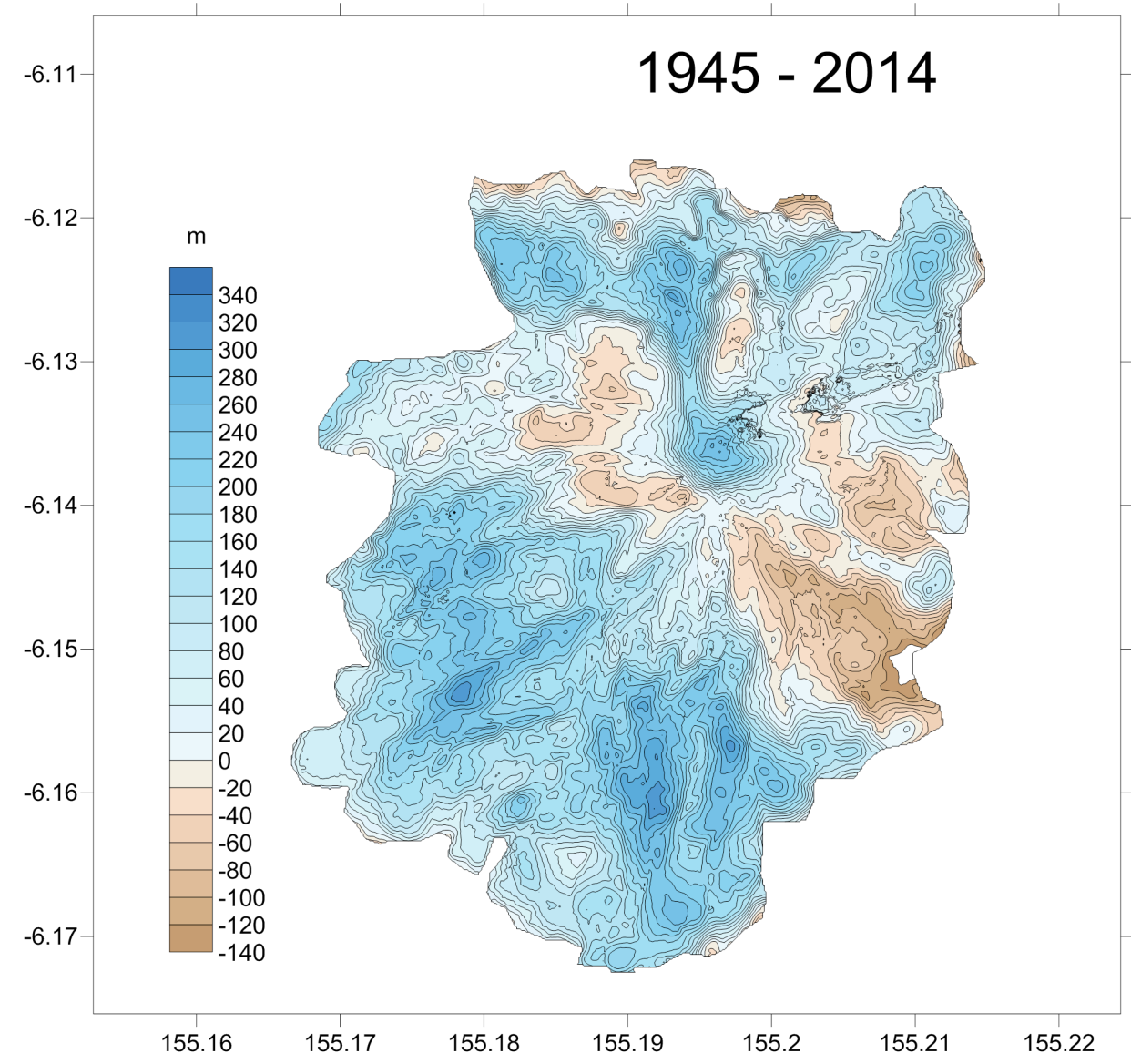

Fig.8 Lava flow thickness change (contours every $20 \mathrm{~m}$ ) measured over 70 years (1945 2014) from the difference between the 1945 and TanDEM-X DEMs.

\section{Combined Results}

Fig. 9 shows the volumes erupted over the intervals measured (Table 2). A linear fit is made through the 1-year, 3-year, 9-year, 15-year, 70-year intervals and the 300 year/Model 3 values, indicating that the extrusion rate of lava has remained near constant at about $1.0 \mathrm{~m} \mathrm{~m}^{3} \mathrm{~s}^{-1}$. The one data point that does not fit this line is that for 2012-2014, which may be due to an underestimate of lava volume. For a scenario in which extrusion at Bagana begins soon after the Billy Mitchell BM2 event a slowly accelerating behaviour for edifice model 2 is required as shown in Fig. 9 (dashed line). There is no other information currently available to choose among these slowstart scenarios. We have not tried to normalize these volumes to the equivalent of dense rock, nor have we accounted for the mass of tephra and ash. Relatively frequent ash venting currently occurs at Bagana (see weekly reports of the Global Volcanism Program) but lack of local measurements currently prevents mass estimation.

We have used the 14-month long average extrusion rate of Wadge et al. (2012). The 11-day sampling rate of their study also allowed them to recognise pulses of lava emission with periods of several months. Here we emphasise the constancy of the extrusion rate over decades, but propose that sub-yearly pulses may also be a characteristic of Bagana's behaviour over the long-term. 


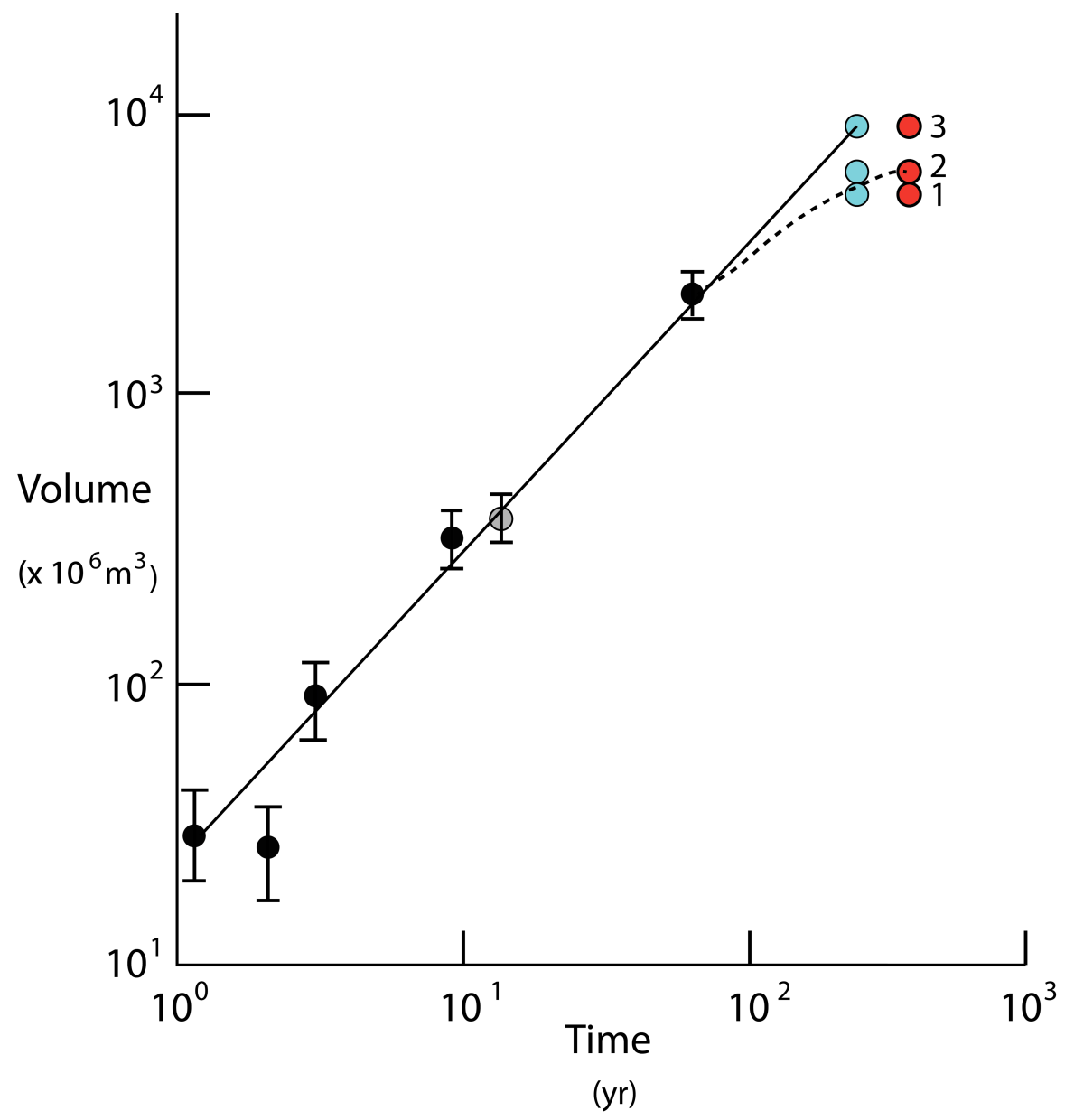

Fig. 9 Plot of the volume - time intervals for estimating extrusion rate (1-year, 2-years, 3years, 9-years (15-years) and 70-years) as black circles with standard deviation bars. Note that the grey circle is the 15-years interval sum of the 9-, 3- and 2-year intervals. The red and blue circles are the modelled edifice volumes (1,2 and 3) placed at 437 years ago (age of BM2 event) and 300 years ago respectively. The straight line has a gradient of $1.0 \mathrm{~m}^{3} \mathrm{~s}^{-1}$ extrusion rate starting 300 years ago on a Model 3 basement The dashed line shows a more gradual development of extrusion rate starting at 437 years ago on a Model 2 basement.

\section{Implications}

The rate of growth of Bagana

The youthfulness of Bagana has been long suspected. Cooke and Johnson (1978) suggested an edifice with a volume of $3-5 \mathrm{~km}^{3}$ might have been built in $500-2000$ years. Rogerson et al. (1989) wrote "Preliminary calculations based on estimates of lava flow volumes (from aerial photographs) between 1943 and 1987 indicate a lava output rate of about 20 million $\mathrm{m}^{3}$ per year. At this rate the whole lava cone could have been produced in about 300 years". This is a volume of about $6 \mathrm{~km}^{3}$ emplaced at a rate of $0.63 \mathrm{~m}^{3} \mathrm{~s}^{-1}$. Our more quantitative results are generally supportive of this 
earlier work, though they indicate that the output rate has been as high as $1 \mathrm{~m}^{3} \mathrm{~s}^{-1}$ during the last 70 years of growth of Bagana.

Connections to local volcanoes?

Three general scenarios can be used to explain the growth of Bagana in relation to its neighbours:

1. Bagana is several thousands of years old or more. The last 70 years of activity have been prolific, but this follows many years (centuries) of inactivity or shallow intrusion. The recent activity has buried all trace of the BM2 fallout deposit on the earlier surface of the volcano. Bagana is not related to the magma source of Billy Mitchell volcano.

2. A new volcano, Bagana, began its growth immediately after the BM2 plinian eruption of Billy Mitchell in $370 \pm 19 \mathrm{yr}$ BP. During the BM2 eruption the volcano suffered caldera collapse and lost access to rising magma beneath it. Instead, the magma quickly found its way laterally by a dyke and erupted $6 \mathrm{~km}$ to the SSW at Bagana (solid line in Fig. 9). The Billy Mitchell-Bagana system is much less explosive in character than Billy Mitchell alone.

3. The BM2 eruption initiated the same blocking mechanism for magma at Billy Mitchell as in 2, but extrusion of andesite lava did not begin, or was at a much lower rate, at Bagana until about 150 years later, after a new, stable pathway to the surface was formed (dashed line in Fig. 9).

The independent sources of volume and extrusion rate, coupled with the range of likely edifice volumes of Bagana give strong support to the idea that Bagana is only a few hundred years old and thus scenario 1 is thought to be much less likely than either 2 or 3 . This raises the question as to whether the last caldera collapse of Billy Mitchell volcano initiated growth of Bagana volcano. In variants of scenarios 2 and 3 , the Reini volcano was active during the 567 years between the BM1 and BM2 events, fed by the Billy Mitchell magma source. Following BM2, magma was redirected from Reini to Bagana (Fig. 10b). In such scenarios we would expect to find BM2 deposits on Reini, which is the case according to Rogerson et al. (1989).

The limnology of the Billy Mitchell lake was studied in 2015 (Schabetsberger et al., 2017). The water column (maximum $88 \mathrm{~m}$ depth) had a near constant temperature $\left(\sim 25^{\circ} \mathrm{C}\right)$, constant, neutral $\mathrm{pH}$ and no accumulation of $\mathrm{CO}_{2}$ at depth. This indicates that there is no leakage of magmatic fluids or gases into the lake, probably since the time of BM2, a conclusion that strengthens the argument for a divergence of magmatic pathways beneath Billy Mitchell.

What is the relationship between the rates of eruption at Bagana and at Billy Mitchell during and after the BM1, BM2 eruptions? To test this we must convert the "topographic" volumes for Bagana and the "deposit" volumes for BM1, BM2 after conversion to a common DRE volume using densities for dense rock $\left(2600 \mathrm{~kg} \mathrm{~m}^{-3}\right)$, lava $\left(2250 \mathrm{~kg} \mathrm{~m}^{-3}\right)$, ignimbrite (pyroclastic flow) $\left(2000 \mathrm{~kg} \mathrm{~m}^{-3}\right)$ and fallout $\left(1200 \mathrm{~kg} \mathrm{~m}^{-}\right.$ ${ }^{3}$ ) of Wadge et al. (2010). We stress that these are not Bagana-specific values. The interval between the BM1 and BM2 eruptions is 567 years and from BM2 to 2017 is 
437 years. The volume of magma erupted in BM2 was about $13.5 \mathrm{~km}^{3}$ comprising $9.5 \mathrm{~km}^{3}$ of ignimbrite and $4 \mathrm{~km}^{3}$ of pumice and phreatomagmatic plinian fallout and that for BM1 was $7 \mathrm{~km}^{3}$ of fallout deposit (Rogerson et al., 1989). Under model 3 (Fig. 6) the Bagana edifice has a volume of $9.6 \mathrm{~km}^{3}$ and the erupted DRE volume of BM2 is about $9.1 \mathrm{~km}^{3}$. The rough similarity of these figures indicates that magma supply to Billy Mitchell between BM1 and BM2, and to Bagana between BM2 and the present day, was of similar vigour and could, on these grounds, perhaps share the same deep source.

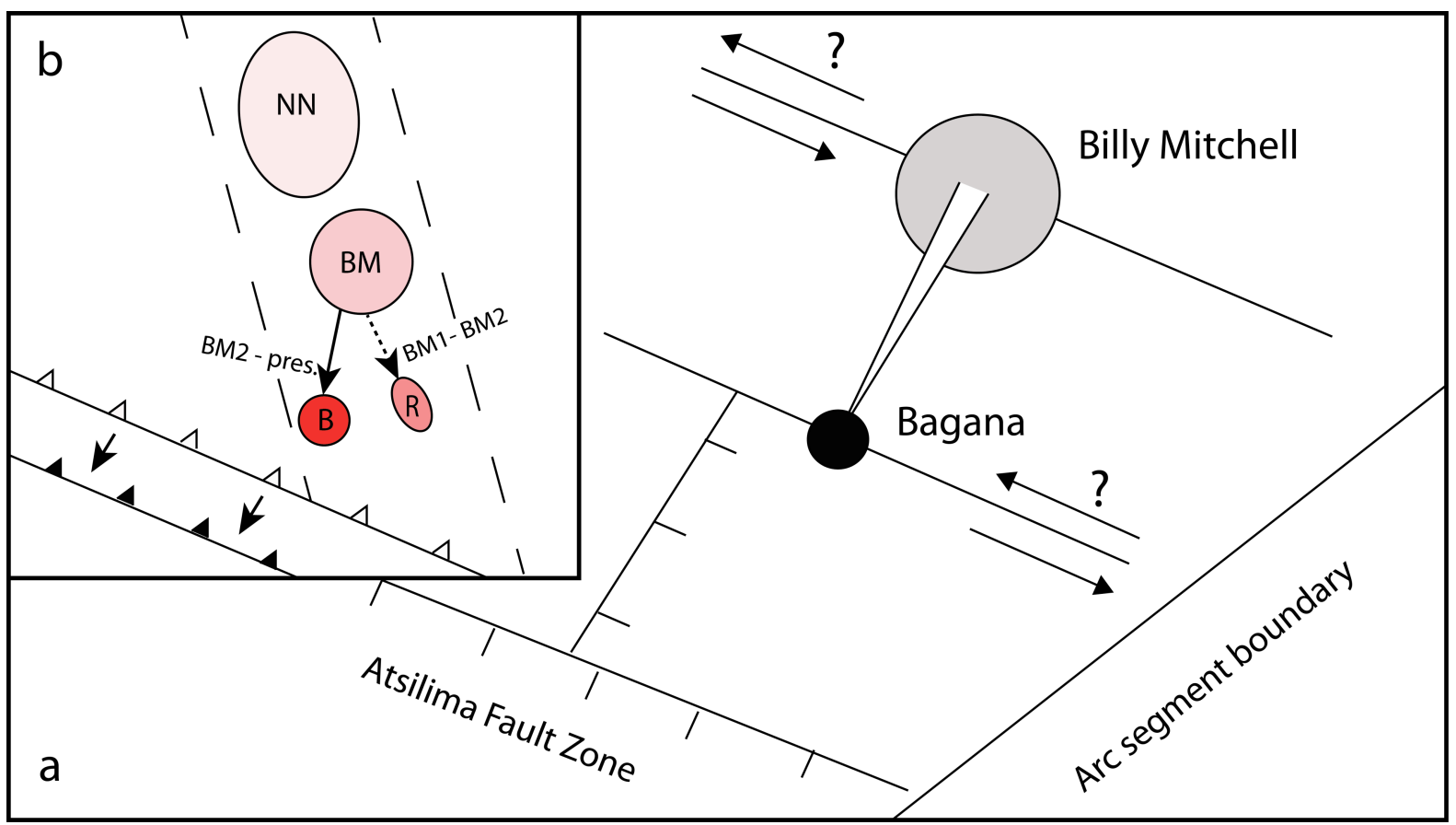

Fig.10 (a) Tectonic sketch map of the possible trans-tensional origin of a magmatic connection between Billy Mitchell volcano and Bagana volcano, (b) Tectonic sketch map of the possible slab roll-back explanation (twin arrows showing movement of trench) for the Numa Numa $(N N)$ - Billy Mitchell $(B M)$ - Reini $(R)$ - Bagana $(B)$ migration of volcanism with time (from pink to red). Between the BM1 and BM2 events magma may have been diverted (arrows) to Reini and then to Bagana between BM2 and the present.

The case for the youthfulness of Bagana does not depend on a causal link to the BM2 eruption of Billy Mitchell volcano. But the question of "why there and then?" arises with regard to Bagana's origin. Several lines of evidence may be relevant: magma budgets, seismological, geodetic, petrological and tectonic. Unfortunately, there is no local relevant seismic or geodetic (e.g. InSAR) data yet available to detect shallow magma transport along an inclined conduit between Billy Mitchell and Bagana.

Tectonic Mechanisms

The tectonic mechanisms affecting Bagana and Billy Mitchell volcanoes may be relevant to any connectivity of their magma supplies. Firstly, the trace of the arc 
segment boundary between Northwestern and Southeastern Bougainville identified by Chen et al. (2011) is shown in Figures 1 and 2. Bagana is located within about 10 $\mathrm{km}$ of this discontinuity. Secondly, Manea et al. (2014) modelled the effect of discontinuities in the subducting plate (e.g. topographic ridges) and showed that there could be enhanced transport of fluids to depth and increased magma production as a result, originating from near such a discontinuity. Such a discontinuity has yet to be identified. Thirdly, the Solomon Islands are arranged in an en echelon pattern formed by motion on ESE-trending left-lateral faults perhaps created by the oblique collision of the Ontong Java Plateau (Rogerson et al., 1989, Holm et al., 2016). However, the existence of earlier strike-slip faulting in Bougainville is hypothetical. We speculate that the ESE and the NNE lineaments of central Bougainville form a network of normal and strike-slip faults (Rogerson et al., 1989) (Fig. 10a). The ESE faults have both normal and left-lateral components of motion; the NNE faults have normal motion and are terminated by the ESE set. Such a combination of inferred fault motions in a block-faulting regime provides an environment favourable to magma transport (e.g. Morgan et al., 2008). A NNE fault could have the correct orientation to link Billy Mitchell and Bagana, though it is not known if such a fault exists. Also, we have no evidence supporting active strike-slip motion on the ESE faults.

The trend of the Numa Numa-Billy Mitchell-Reini-Bagana line of volcanism is oblique $\left(165^{\circ}\right)$ to the Tore-Balbi-Bagana volcanic front $\left(137^{\circ}\right)$ and there is a general reduction of age along this line from NNW to SSE (Rogerson et al., 1989). Slab rollback to the southwest of the subducting Solomon Sea plate could explain this (e.g. Menant et al., 2016), as the result of steepening of the subducting slab and migration of the volcanic front towards the trench (Fig.10b).

\section{Evolution of Bagana}

It may be that the three volcanoes discussed, Bagana, Billy Mitchell and Reina have independent systems of magma supply from their sources in the mantle wedge. In this case their evolution may be entirely uncorrelated. Bagana may carry on in its current lava cone building and the conditions that caused Reini to stop erupting do not affect Bagana. If there is no link between Bagana and Billy Mitchell then we might see another plinian eruption from Billy Mitchell, but no change in the behaviour of Bagana.

If the magmatic systems are connected, say sharing a crustal reservoir, then we might expect more synchronised behaviour. For example, Bagana's long-term extrusion rate may fall to much lower values or stop, thus allowing the Billy Mitchell reservoir to re-energise, leading to another plinian event. This in turn could trigger the creation of a "new" Bagana in another location.

The eruptive products of Billy Mitchell volcano are dominated by hornblende andesite-dacite tephra and ignimbrite, very different from the basaltic andesite lavas of Bagana and Reini. However, Bagana lavas do contain some large $(\sim 15 \mathrm{~cm})$ coarse-grained dacitic inclusions (Bultitude et al, 1978) that could be a link to Billy Mitchell magma. 


\section{Discussion}

Bagana is an unusual volcano that has been little studied. This paper raises a number of questions that we are currently unable to answer. Here we briefly discuss some of the more pressing, such as: What is the source of the andesite magma at Bagana and how is it related to the Billy Mitchell magma? Do the high fluxes of magma and gas and the relatively low level of explosivity imply a very open system? Does Bagana's magmatic conduit deviate from the vertical? Are there other andesite volcanoes with a similar character?

Bultitude et al. (1978) argued that the recent lavas of Bagana could act as a "reference" andesite whole rock composition for the Papua New Guinea region, given the rare availability of a good time series of samples. From such a time series, a study of glassy melt inclusions in crystals could provide information on liquids during andesite magma formation (e.g. Reubi and Blundy, 2009), particularly magma mixing processes.

The persistence over decades of high rates of magma extrusion and high gas flux is unusual and characteristic of Bagana. This contrasts with a volcano such as Santiaguito that displays a strong decadal periodicity of magma extrusion (Ebmeier et al., 2012). These rates suggest a source of sulphur much greater than that available from the flux of andesite magma. Another source of volatiles is required to supply this "missing" gas. Are these high rates related to the extreme subduction zone setting of Bougainville discussed earlier?

Frequent minor explosions with and without ash are known from Bagana (e.g. Wadge et al., 2012) but are little studied. Capping of the conduit with a chilled lava dome, or development and release of pressure due to fracturing at the magma column margins are popular mechanisms. Bagana lava has a high dynamic bulk viscosity $\left(\sim 3 \times 10^{10} \mathrm{~Pa} \mathrm{~s}\right.$, Wadge et al., 2012) and Holland et al. (2011) modelled the viscosity required for shear fracturing at the conduit boundary of Santiaguito volcano as $10^{10}-10^{12} \mathrm{~Pa}$ s. Closer analysis of explosion source and deposits and explosion dynamics should improve our understanding. If the edifice of Bagana is susceptible to "closed" pressurization over periods of several days, then satellite-based InSAR may be able to measure the resultant surface deformation cycle. But if the pressurization cycle is at a much shorter period (e.g. Santiaguito interval $=26$ minutes, Johnson et al., 2014), then the InSAR deformation signal will be aliased and lost.

A mid- to upper-crustal conduit between Billy Mitchell and Bagana may be nonvertical. Seismic detection of inclined magma transport in such a conduit may be possible if a local seismic network were available. For example, inclined magma transport from $20 \mathrm{~km}$ depth on a $45^{\circ}$ conduit was evident from seismicity at Mt Unzen (Umakoshi et al., 2001). InSAR may also be able to detect this, but given the poor radar coherence away from the slopes of Bagana this is unlikely.

Identifying volcanoes similar in character could give insight into shared patterns of behaviour. The "birth" of new basaltic polygenetic volcanoes, such as Cerro Negro in Nicaragua (1850-present) (McKnight and Williams, 1997) and Izalco in El Salvador (1770-1966) (Carr and Pontier, 1981) is recognised. There are also some well- 
studied andesitic systems such as Arenal in Costa Rica that are a few thousand years old (Soto and Alvarado, 2006), but those only a few hundred years old are rare. El Metate shield volcano in Mexico (Chevrel et al., 2016) is comprised entirely of andesite lava flows, with a similar total volume to Bagana, that were emplaced over a period of about 50 to 100 years (Mahgoub et al., 2017). However, El Metate is a monogenetic volcano in the Michoacan Guanajuato volcanic field that seems to have involved the eruption of two distinct andesitic magma batches.

\section{Acknowledgements}

GW, BTMK and ME are grateful to the NERC/COMET consortium for support during this work. We are also grateful for access to TanDEM-X global data under DLR project DEM-GEOL0911. The Bodleian Library at Oxford was very helpful in accessing a copy of the 1945 map. We thank the staff at RVO for their help with observational data. Helpful reviews by N. Varley and another allowed us to improve our manuscript.

\section{References}

Blake, D.H., 1968. Post Miocene volcanoes on Bougainville Island, Territory of Papua New Guinea. Bull. Volcanol., 32, 121-138.

Blake, D.H., Miezitis, Y., 1967. Geology of Bougainville and Buka Islands, New Guinea. Bur. Min. Resour. Austr. Bull. 93,56pp.

Bolge, L.L., Carr, M.J., Milidakis, K.I., Lindsay, F.N., Feigenson, M.D., 2009. Correlating geochemistry, tectonics and volcanic volume along the Central American volcanic front. Geochem. Geophys. Geosystems, 10/12, Q12S18.

Bougainville Island 1945. Torokina sheet, 4895, Australian Survey Corps, One-inchto-one-mile map series.

Branch, C.D., 1967. Short papers from the Volcanological Observatory, Rabaul, New Britain. Bur. Miner. Resour. Austr. Rep. 107, 11-15.

Briffa, K.R., Jones P.D., Schweingruber, F.H., Osnorn, T.J., 1998. Influence of volcanic eruptions on Northern Hemisphere summer temperature over the past 600 years. Nature, 393, 450-455.

Bultitude, R.J., 1976. Eruptive history of Bagana volcano, Papua New Guinea, between 1882 and 1975. In, Johnson, R.W. (ed.) Volcanism in Australasia, Elsevier, Amsterdam, 317-336.

Bultitude, R.J., Johnson, R.W., Chappell, B.W., 1978. Andesites of Bagana volcano, Papua New Guinea: chemical stratigraphy and a reference andesite composition. BMR J. Austr. Geol. Geophys., 3, 281-295.

Bultitude, R.J., 1981. Literature search for pre-1945 sightings of volcanoes and their activity on Bougainville Island. In, Johnson R.W. (ed.) Cooke-Ravian volume of volcanological papers. Geological Survey of Papua New Gunea, Memoir 10, 227-242.

Bultitude, R.J.,Cooke, R.J.S., 1981 Note on activity from Bagana volcano from 1975 to 1980 . In, Johnson R.W. (ed.) Cooke-Ravian volume of volcanological papers. Geological Survey of Papua New Guinea, Memoir10, 243-248. 
Carn, S.A., Fioletov, V.E., McLinden, C.A., Krtokov, N.A., 2017. A decade of global $\mathrm{SO}_{2}$ emissions measured from space. Nature Sci. Reports, 7:44095, doi:10.1038/srep44095.

Carr, M.J., Pontier, N.K., 1981. Evolution of a young parasitic cone towards a mature central vent: Izalco and Santa Ana volcanoes in El Salvador, Central America. J. Volcanol. Geotherm. Res.,11/204, 277-292.

Chen, M.-C., Frohlich, C., Taylor, F.W., Burr, G., Quarles van Ufford, A., 2011. Arc segmentation and seismicity in the Solomon Islands arc, SW Pacific. Tectonophys., 50747-69.

Chevrel, M.O.. Guilbaud, M-N., Siebe, C., 2016. The AD 1250 effusive eruption of El Metate shield volcano (Michoacan, Mexico): magma source, crustal storage, eruptive dynamics and lava rheology. Bull. Volcanol. 78:32 doi: 10.1007/s00445016-1020-9.

Cooke, R.J.S., Johnson, R.W., 1978. Volcanoes and volcanology in Papua New Guinea. Geological Survey of Papua New Guinea, Report 78/2.

DLR, 2016. TanDEM-X ground segment DEM products specification document. TDGS-PS-0021.

Ebmeier, S.K., Biggs J. Mather T.A., Elliott, J.R., Wadge, G., Amelung, F. (2012) Measuring large topographic change with InSAR. Earth Planet. Sci. Lett. 335336, 216-225, doi:101016/l.epsl.2012.04.027.

Farr, T. G., Rosen, P.A., Caro, E., Crippen, R., Duren, R., Hensley, S., Kobrik, M., Paller, M., Rodriguez, E., Roth, L., Seal, D., Shaffer, S., Shimada, J., Umland, J., Werner, W., Oskin, M., Burbank, D., Alsdorf, D., 2007. The Shuttle Radar Topographic Mission. Rev. Geophys., 45, RG2004, doi:10.1029/2005RG00183.

Fisher, N.H., 1956. Report of the sub-committee on volcanology 1954-56. Austr. Nat. Committee, Geodesy and Geophysics.

Fisher, N.H., 1957. Catalogue of the active volcanoes of the world including solfatara fields. Part V, Melanesia, Napoli, Internat. Volcanol. Assoc.

Furumoto, A.S., Hussong, D.M., Campbell, J.F., Sutton, G.H., Malahoff, A., Rose, J.C., Woolard, G.P. 1970. Crustal and upper mantle structure of the Solomon Islands as revealed by seismic refraction survey of November - December 1966. Pacific Sci., 24.

Grove, T.L., Till, C.B., Chatterjee, N., Medard, E., 2009. Kinematic variables and water transport formation and location of arc volcanoes. Nature, 459, 694-697.

Guppy, H.B., 188. The Solomon Islands: their geology, general features and suitability for colonisation. Swan, Sonnenschein, Lowery and company, London, 21-22.

Holland, A.S.P., Watson, I.M., Phillips, J.C., Caricchi, L., Dalton, M.P. 2011. Degassing processes during lava dome growth: insights from Santiaguito lava dome, Guatemala. J. Volcanol. Geotherm. Res., 202, 153-166.

Holm, R.J., Rosenbaum, G., Richards, S.W., 2016. Post-8 Ma reconstruction of Papua New Guinea and Solomon Islands: microplate tectonics in a convergent plate boundary setting. Earth Science Reviews, 156, 66-81.

Jaber, W.A., Floricioiu, D., Rott, H., Eineder, M., 2013. Surface elevation changes of glaciers derived from SRTM and TanDEM-X DEM differences. IEEE IGARSS Proceedings, Melbourne, 1893-1896.

Johnson, J.B., Lyons, J.J., Andrews, B.J., Lees, J.M., 2014. Explosive dome eruptions modulated by periodic gas-driven inflation. Geophys. Res. Lett., 41, 6689-6697, doi: 10.1002/2014GL061310. 
Johnson, R.W., 2013. Fire mountains of the islands: a history of volcanic eruptions and disaster management in Papua New Guinea and the Solomon Islands. ANU, (EPress).

Lay, T., Ye, L., Ammon, C.J., Kanamori, H., 2017. Intra-slab rupture triggering megathrust rupture co-seismically in the 17 December 2016 Solomon Islands $M_{w}$ 7.9 earthquake. Geophys. Res. Lett., 44, 1286-1292, doi:10.1002/2017GL072539.

Mahgoub, A.N., Bohnel, H., Siebe, C., Chevrel, M.O., 2017. Paleomagnetic study of El Metate shield volcano (Michoacan, Mexico) confirms its monogenetic nature and young age ( 1250 CE). J. Volclanol. Geotherm. Res., 336, 209-218.

McCormick, B.T., Edmonds, M., Mather, T., Carn, S., 2012. First synoptic analysis of volcano degassing in Papua New Guinea. Geochem., Geophys., Geosystems,13(3) Q03008, doi: 10.1029/2011GC003945. .

McCormick Kilbride, B.T., Mulina, K., Wadge, G., Johnson, R.W., Itikarai, I., Edmonds, M. (in prep. a) Multi-year satellite observations of sulphur dioxide gas emissions and lava extrusion at Bagana volcano, Papua New Guinea. Frontiers Earth Science.

McCormick Kilbride, B.T., Salem, L.C., Ellis, B. et al. (in prep. b) Geochemical and petrological analyses of andesite lavas from Bagana volcano, PNG.

McGonigle, A.J.S., Oppenheimer, C., Tsanev, V.I., Saunders, S., Mulina, K., Tohui, S., Bosco, J., Nahou, J., Kuduon, J., Tarani, F., 2004. Sulphur dioxide fluxes from Papua New Guinea's volcanoes. Geophys. Res. Lett., 31, L08606.

McKnight, S.B., Williams, S.N., 1997. Old cinder cone or young composite volcano?: the nature of Cerro Negro, Nicaragua. Geology, 25/4, 339-342.

Menant, A., Sternai, P., Jolivet, L., Guillou-Frottier, L., Gerya, T., 2016. 3D numerical modelling of mantle flow, crustal dynamics and magma genesis associated with slab roll-back and tearing: The eastern Mediterranean case. Earth Planet Sci. Lett., 442, 93-107.

Manea, V.C., Leeman, W.P., Gerya, T., Manea, M., Zhu, G., 2014. Subduction of fracture zones controls mantle melting and geochemical signature above slabs. Nature Comm., 5:5095, doi:10.1038/ncomms6095.

Morgan, J.P., Ranero, C.R., Vannucchi, P., 2008. Intra-arc extension in Central America: links between plate motions, tectonics, volcanism and geochemistry. Earth Planet, Sci., Lett., 272, 365-371.

Nuth, C., Kaab, A., 2011. Co-registration and bias corrections of satellite elevation data sets for quantifying glacier thickness change. The Cryosphere, 5, 271-290, doi:10.5194/tc-5-271-2011.

Reubi, O., Blundy, J., 2009. A dearth of intermediate melts at subduction zone volcanoes and the petrogenesis of arc volcanoes. Nature, 461, doi:10.1038/nature08510.

Rogerson, R.J., Hilyard, D.B., Finlayson, E.J., Johnson, R.W., McKee, C.O., 1989. The geology and mineral resources of Bougainville and Buka islands, Papua New Guinea. Geological Survey of Papua New Guinea, Memoir 16, 217 pp.

Schabetsberger, R., Sichrowsky, U., Scheck, A., Schagerl, M., Mahnurt, B., Sonntag, B., Paul K., 2017. First limnological characterization of Crater Lake Billy Mitchell (Bougainville Island, Papua New Guinea). Pacific Science, 71(1), 29-44.

Siebert, T., Simkin, T., Kimberley, P., 2010. Volcanoes of the world. Smithsonian Institution, University of California Press, p.79.

Smith, I.E.M., Nemeth, K., 2017. Source to surface model of monogenetic volcanism: a critical review. In, Nemeth, K., Carasco-Nunez, G., Arania-Gomez, J.J., Smith, 
I.E.M. (eds.) Monogenetic volcanism, Geological Society, London, Special Pub., 446, 1-28.

Soto, G.J., Alvarado, G.E., 2006. Eruptive history of Arenal Volcano, Costa Rica, 7 ka to present. J. Volcanol. Geotherm. Res., 157, 1/3, 2540269.

Syracuse, E.M., Abers, G.A., 2006. Global compilation of variations in slab depth beneath arc volcanoes and implications. Geochem., Geophys., Geosystems, 7/5 Q05017 doi:10.1029/2005GC001045.

Taylor, G.A., 1956. Review of the volcanic activity in the territory of Papua-New Guinea, The Solomon and New Hebrides Islands, 1951-53. Bull. Volcanol., Serie II,18, 25-37.

Umakoshi, K., Shimizu, H., Matsuwo, N. Volcano-tectonic seismicity at Unzen Volcano, Japan, 1985-1999. J. Volcanol. Geotherm. Res., 112, 117-131.

Wadge, G., Saunders, S., Itikarai, I., 2012. Pulsatory andesite lava flow at Bagana Volcano. Geochem. Geophys. Geosystems, 13, Q11011, doi: 10.1029/2012GC004336. 